
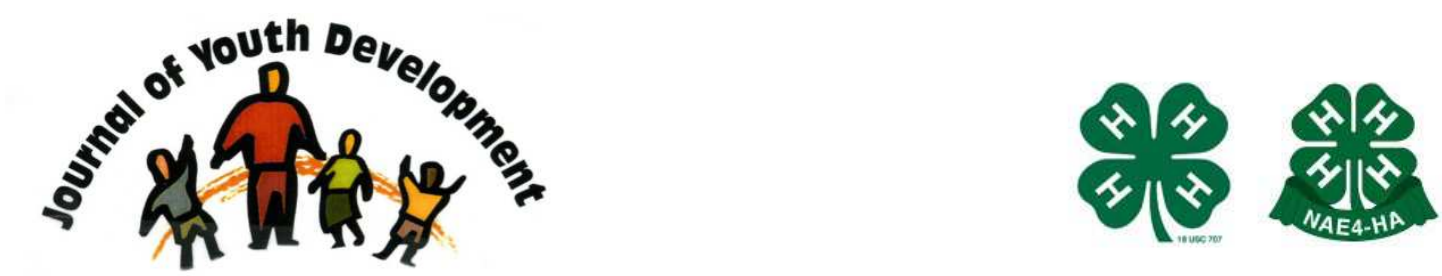

Bridging Research \& Practice

\title{
Addressing the Needs of Children of Offenders: The 4-H LIFE Model
}

\author{
Lynna J. Lawson \\ University of Missouri Extension \\ Farmington, Missouri \\ lawsonl@missouri.edu \\ Robert C. Wilkerson \\ University of Missouri Extension \\ wilkersonrc@missouri.edu \\ Tammy Gillespie \\ University of Missouri Extension \\ gillespiet@missouri.edu \\ Elizabeth G. Dunn \\ Impact LLC \\ edunn@impactllc.net \\ J. Gordon Arbuckle \\ Iowa State University Extension \\ arbuckle@iastate.edu \\ L. Jo Turner \\ University of Missouri Extension \\ turnerlj@missouri.edu
}




\title{
JOURNAL OF YOUTH DEVELOPMENT \\ bridging research and practice

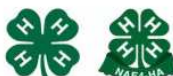

\section{Addressing the Needs of Children of Offenders: The 4-H LIFE Model}

Lynna J. Lawson, Robert C. Wilkerson, Tammy Gillespie, and L. Jo Turner University of Missouri

J. Gordon Arbuckle

Iowa State University

Elizabeth G. Dunn

Impact LLC

\begin{abstract}
H LIFE represents a promising approach to addressing the needs of children of offenders and their caregivers. The 4-H Living Interactive Family Education (LIFE) Program was established in 1999 at the Potosi Correctional Center, a maximum security prison. 4-H LIFE is an enhanced or therapeutic visitation program with three key components:

1. parent engagement

2. parent education

3. 4-H activities for children of offenders, led by the incarcerated parents.

Since inception, 141 youths between the ages of 5 and 18 have participated; 59 incarcerated fathers and 106 caregivers have also been engaged at PCC. Program evaluations suggest that parent-child outcomes improved. In 2005, 4-H LIFE received the Annie E. Casey Foundation Family Strengthening Award.
\end{abstract}

\section{Introduction}

Over 2.1 million men and women are incarcerated at federal, state and local levels (Bureau of Justice Statistics, 2007). It is estimated that $60 \%$ of male and $70 \%$ of female offenders have 
minor children. On any given day, more than 2 million US children and teens have an incarcerated parent (CCIP, 2001). Research on children with incarcerated parents suggests that the impact on children and adolescents can be significant.

Separation from parents by prison can be devastating, resulting in feelings of abandonment, sadness, and anger, and can lead to eating and sleeping disorders, lower academic performance, and disruptive behavior (Block, \& Potthast, 2001; Johnston, 1995a). Without intervention, as many as $70 \%$ of these children are likely to become involved with the criminal justice system (Tierney, \& Grossman, 2000).

Enhanced or therapeutic visitation is an approach that seems to mitigate some of the negative effects of parental incarceration. Enhanced visitation addresses the need for physical and emotional interaction between many children and their parents. Most traditional visit settings in correctional facilities are restrictive, allowing only minimal interaction and physical contact between parent and child. In contrast, enhanced visitation programs allow children and parents to interact more naturally in child-oriented environments (Johnston, 1995a). Children who visit their incarcerated parents score higher on measures of well-being, IQ, emotional adjustment and behavioral measures (Johnston, 1995b).

\section{4-H LIFE Program}

The 4-H Living Interactive Family Education (LIFE) Program was established in 1999 at the Potosi Correctional Center (PCC), a maximum security prison in Washington County, Missouri. The program was initially funded as a United States Department of Agriculture's Children, Youth and Families at Risk (CYFAR) project. The Missouri CYFAR project team included faculty from the University of Missouri Extension in 4-H Youth Development and Human Environmental Sciences and from Lincoln University Cooperative Extension.

The Missouri CYFAR project team, county 4-H/Extension educators, community leaders, incarcerated fathers, and prison administrators worked over a six-month period to develop and refine program goals. The overall objective for 4-H LIFE became: "To promote a strong, healthy, and nurturing family environment for children of incarcerated parents, while helping incarcerated parents become positive role models and mentors." A program logic model was developed targeting long-term outcomes, including:

- Children's self-esteem and social skills are improved

- Children become better citizens and leaders

- Children stay in school longer

- Children's sense of isolation is reduced

- Children's risk of incarceration is reduced

- Children and fathers maintain long-term relationship

- Stress levels are reduced for fathers and prison workers

- Recidivism is reduced

Incarcerated fathers worked with 4- $\mathrm{H}$ and PCC staff to form a recognized organization within the prison, including by-laws and elected officers. All participants, including offenders, children, and caregivers, were members of 4-H LIFE. Offender participants included fathers, grandfathers, and stepfathers as well as men with on-going, approved visits with nieces, 
nephews, and other close relatives between the ages of 5 and 19. References to incarcerated fathers and parents represent this broad array of adult-child relationships.

4-H LIFE was designed as an enhanced visitation program with three integrated components: parent engagement, parent education, and 4-H activities.

1) Parent engagement: Incarcerated fathers at PCC participated in monthly planning and business meetings with PCC and 4-H staff. Fathers prioritized 4- $\mathrm{H}$ activities they would like to lead in visitation sessions and made decisions about resources needed to carry out the activities such as funds, supplies and assigned tasks. The offenders shared information pertaining to their unique needs and situations. Planning meetings built ownership, resulting in a dramatic shift in offender perception. As a result, staff were seen as partners rather than service providers. These meetings were an essential connection between parenting classes and visitation, as the fathers planned how to use new parenting skills during visitation.

4-H LIFE business was also conducted at these monthly sessions. Members discussed day to day operations of the program inside the institution such as fund-raisers, donations to outside charities, and restorative justice projects. For example, one fund-raiser generated 4-H camp scholarships for offenders' children.

2) Parenting education: Monthly parenting classes focused on child development, communication, and positive discipline. These required classes gave offenders skills needed to better connect with their children and reinforced concepts of awareness and responsibility. During parenting classes, 4-H LIFE fathers took part in activities designed to increase their capacity as a parent and role-model. Sessions were taught by Extension educators, trained in working with offenders and certified in selected curricula including Building Strong Families (University of Missouri Human Environmental Sciences Outreach and Extension, 2007) and Tackling the Tough Skills (Trotta, 2000). In addition, Extension educators prepared incarcerated fathers to use peer-reviewed 4-H curricula with their children during 4-H activities.

Early on, parenting classes were conducted for caregivers while the incarcerated fathers held 4-H activities with their children. Caregivers asked to be included during the 4-H activities. This participant-driven change allowed youth, offenders and caregivers to strengthen their family unit as well as build relationships with other families, reducing feelings of isolation. An incarcerated father said, "The LIFE meetings help me by building a stronger bond with our family and sharing with other families in the same circumstances."

3) 4-H activities: Monthly 4-H activities were conducted at PCC using a 4-H club meeting format with pledges, roll call, business, games, educational program, and refreshments. Youth served as 4-H officers and lead the meetings with support from parents, Extension educators and PCC staff. The offender, child and caregiver worked together on 4-H club activities such as crafts or curricula-based activities focusing on subjects such as conflict resolution, communication, and character development. All activities and projects were carefully reviewed and pre-approved by PCC staff.

Regular visitation rules at the PCC required that fathers limit physical contact with their children and remain seated at all times with their hands visible on the tabletop. In contrast, 4-H LIFE meetings included games and songs, resulting in laughter, hugs, and spontaneous conversation. 
One offender described the importance of working with his child at 4-H meetings: "It feels like being a father. You're sharing a father-son relationship and accomplishing something with him."

Today, county 4-H/Extension educators provide day to day leadership for the project, with support from campus-based faculty. Initially, the CYFAR project funded a position in the county. The project is now integrated into 4-H and Extension programming as part of regular assignments. Support and training for $4-\mathrm{H}$ LIFE is provided by the CYFAR project team. In addition, all Extension employees and volunteers who work with the 4-H LIFE program inside PCC must become an official "Volunteer in Corrections." Orientation and annual renewal trainings are provided at no cost by the Department of Corrections.

\section{Outcomes}

Since inception, 141 youths between the ages of 5 and 18 have participated; 59 incarcerated parents and 106 caregivers have also been engaged at PCC. A multi-method evaluation was employed to assess child and parent outcomes. Because of the involvement of minors and incarcerated persons, the project was rigorously reviewed for human subjects' protection before approval.

1) Children: A life skills survey was developed to assess academics, goal setting and achievement, decision making, problem solving, communication, social competencies, and selfesteem. (See Appendix A - Life Skills Survey Instrument.) The instrument was adapted from:

- Rosenberg Self Esteem Scale (Rosenberg, 1965, 1986)

- 4-H Four-Fold Youth Development Model (Barkman, et al., 1999)

- Utah's Youth and Families with Promise Program evaluation tool (Utah State University Extension, 2000)

Over a three-year period, surveys were administered four times. All school age children and youth attending 4-H LIFE on a given day were assessed. However, the remote location, transportation, and status of the offenders meant that only about half the potential children and youth were assessed at each point of measurement. Participant characteristics were:

Age range $-5-17$ years old; Mean age -13 years old

Race/ethnicity: White - 76\%; Multi-racial - 14\%; Black - 10\%

Gender: $90 \%$ Male; $10 \%$ Female

Average sample scores increased slightly over time, but the small sample size and the use of cross-sectional data make the results primarily useful as a pilot study that can inform future research (Dunn, 2003). For full results and analysis, see:

http://muextension.missouri.edu/fcrp/lifeevaluation/life.htm

2) Fathers: Fathers participated in focus groups, attributing several positive impacts to 4-H LIFE, including:

- $\quad$ bonding and stronger parent-child relationship

- improved parent-child communication

- development of life skills such as leadership, empathy, and self-control by child 
- sense of family unity between fathers, children, and caregivers.

- improved behavior and academic performance by child

Fathers also reported that the parenting meetings provided them with greater understanding of what it means to be a father (Dunn, \& Arbuckle, 2002). For results, reports, and focus group protocol, see: http://extension.missouri.edu/fcrp/lifeevaluation/execsummary.htm

3) System: The impact of 4-H LIFE now extends beyond Washington County. Largely as a result of the program, more emphasis is being given to programs for children of offenders and caregivers. In 2004, the CYFAR project team planned and hosted the Children of Offenders Partnership conference to foster support networks between social service providers and caregivers. Three additional communities are replicating 4-H LIFE in Missouri's current CYFAR project, serving incarcerated women as well as men. 4-H LIFE has also been featured in presentations at national youth development conferences. Significantly, 4-H LIFE was selected by the Annie E. Casey Foundation as one of the national Family Strengthening Award winners in 2005. Contact the Family and Community Resource Program, University of Missouri Extension, for replication information, including a program manual and web-based resources at: http://extension.missouri.edu/fcrp/

\section{Recommendations}

1. Establish community support upfront. 4-H LIFE elicited strong feelings-both positive and negative. Initially, a small but vocal group of community members opposed the program. Town hall meetings were held where youth and adults from 4-H Clubs in Washington County along with county and state extension administrators spoke on the importance of working with children of offenders. The process resulted in better understanding of the issues and a stronger commitment to access and opportunity for all youth.

2. Engage all stakeholders in program development, implementation and evaluation. 4-H LIFE is built on the idea that offenders, children, caregivers, corrections staff, community members, and program staff must have ownership for the program to be successful. The needs of each community and correctional facility are unique, so stakeholder input is essential. Whether building the program logic model or modifying the program structure, engagement is critical to successful implementation.

3. Build on-going evaluation into the program from the inception. One of the most powerful tools in creating and sustaining 4-H LIFE has been on-going program evaluation. Program evaluation results have been used to improve the program, educate others, and build support among funders, administrators, and community leaders.

4. Strengthen evaluation strategies and methodologies. At the same time, evaluation findings are limited. Practitioners who replicate 4-H LIFE should use additional methodologies and measures to follow changes in individual children over time. Further, evaluation should expand to include data from key stakeholders such as caregivers. 


\section{Conclusions}

4-H LIFE is a promising approach for mitigating potential negative impacts of parental incarceration for most children of offenders. However, as is the case with much of the research on children with incarcerated parents, the evaluation is limited by a small sample size and simple methodological approaches that measured short-term impacts (Seymour 2001). Further research is needed to examine the impact on children and families over time.

Of critical interest is whether participation in 4-H LIFE contributes to sustained reduction of problem behaviors and improved developmental outcomes for children, adolescents and young adults. Since children of offenders are more likely to become offenders themselves, it is essential to learn whether 4-H LIFE and other enhanced visitation programs can intervene in this cycle.

If current trends in incarceration continue, youth development practitioners and researchers must find ways to support children of incarcerated parents in order to promote positive development and prevent negative outcomes for millions of youths.

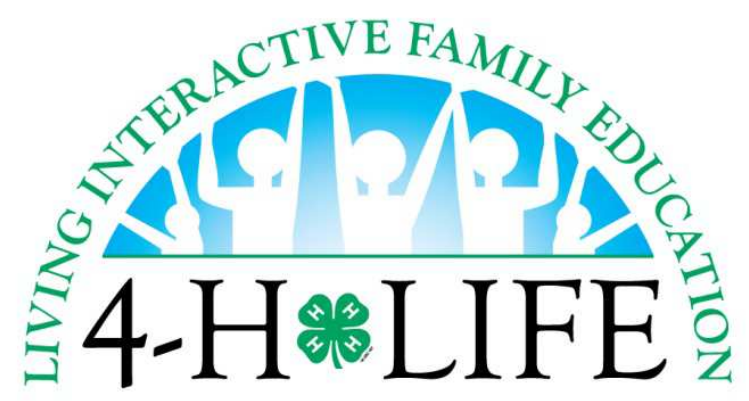

\section{References}

Barkman, S.J., Machtmes, K., Myers, H., Horton, R.L., \& Hutchinson, S. (1999). Four-Fold Youth Development Model, 4-H Publication No. 895. West Lafayette, IN: Purdue University and The Ohio State University.

Block, K.J., \& Potthast, M.J. (2001). Girl Scouts Beyond Bars: Facilitating Parent-Child Contact in Correctional Settings. In C. Seymour \& C.F. Hairston (Eds.), Children with Parents in Prison: Child Welfare Policy, Program, and Practice Issues (pp. 93-110). New Brunswick, NJ: Transaction Publishers.

Bureau of Justice Statistics. (2007). Corrections Statistics. Retrieved January 14, 2007 from http://www.ojp.usdoj.gov/bjs/correct.htm 
CCIP. (2001). How Many Children of Incarcerated Parents Are There? (Data Sheets on Children of Incarcerated Parents No. 3a). Eagle Rock, CA: Center for Children of Incarcerated Parents.

Dunn, E. (2003). Life Skills in Children of Incarcerated Fathers. Retrieved January 14, 2007, from http://muextension.missouri.edu/fcrp/lifeevaluation/life.htm

Dunn, E., \& Arbuckle, J.G. (2002). Children of Incarcerated Parents and Enhanced Visitation Programs: Impacts of the Living Interactive Family Education (LIFE) Program. Retrieved January 14, 2007 from http://muextension.missouri.edu/fcrp/lifeevaluation/life.htm

Johnston, D. (1995a). Effects of Parental Incarceration. In K. Gabel \& D. Johnston (Eds.), Children of Incarcerated Parents (pp. 59-88). New York: Lexington Books.

Johnston, D. (1995b). Intervention. In K. Gabel \& D. Johnston (Eds.), Children of Incarcerated Parents (pp. 199-236). New York: Lexington Books.

Johnston, D. (1995c). Parent Child Visitation in the Jail or Prison. In K. Gabel \& D. Johnston (Eds.), Children of Incarcerated Parents (pp. 135-143). New York: Lexington Books.

Rosenberg, M. (1965). Society and the Adolescent Self-Image. Princeton, NJ: Princeton University Press.

Rosenberg, M. (1986). Conceiving the Self. Malabar, FL: Krieger.

Seymour, C.B. (2001). Children with Parents in Prison: Child Welfare Policy, Program, and Practice Issues. In C. Seymour \& C.F. Hairston (Eds.), Children with Parents in Prison: Child Welfare Policy, Program, and Practice Issues (pp. 1-25). New Brunswick, NJ: Transaction Publishers.

Tierney, J.P., \& Grossman, J.B. (2000). Making a difference: An impact study of Big Brothers Big Sisters. Philadelphia, PA: Public/Private Ventures.

Trotta, R. (2000). Tackling the Tough Skills: A Curriculum Building Skills for Work and Life (Extension Publication CB13). Columbia, MO: University of Missouri-Columbia.

University of Missouri Human Environmental Sciences Outreach and Extension. (2007). Building Strong Families. Retrieved September 25, 2007 from http://extension.missouri.edu/bsf/

Utah State University Extension. (2000). Utah State Youth and Families with Promise (YFP) Evaluation Instrument. Logan, UT: Utah State University.

(C) Copyright of Journal of Youth Development $\sim$ Bridging Research and Practice. Content may not be copied or emailed to multiple sites or posted to a listserv without copyright holder's express written permission. Contact Editor at: patricia.dawson@oregonstate.edu for details. However, users may print, download or email articles for individual use.

ISSN 2325-4009 (Print); ISSN 2325-4017 (Online) 


\section{Appendix - A - Life Skills Survey Instrument \\ The Living Interactive family Education (LIFE) Program \\ POTOSI, MO \\ LIFE SKILLS SURVEY \\ CYFAR IMPACT EVALUATION}

1. How old are you?

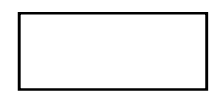

DATE

2. Are you male or female?

$\square$ male

$\square$ female

3. What is your race or ethnicity?

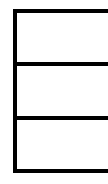

White, not of Hispanic Origin

American Indian or Alaskan Native

Asian or Pacific Islander

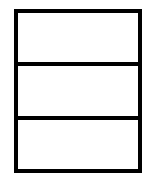

Black, not of Hispanic Origin

Hispanic

Multi-Racial

4. What grade are you in? (If school is out for the summer, what grade did you just finish?)

5. About when did you first come to the 4-H LIFE Program?

$\square$ sometime in the past month

$\square$ one to three months ago

$\square$ more than three months ago

6. About how many of the meetings do you come to?

$\square$ all the meetings

$\square$ most of the meetings

$\square$ half of the meetings

$\square$ less than half of the meetings 


\section{SECTION 2}

Directions: Read each statement and circle the answer that best describes you at the present time. The answers range from 1, which means "never", to 5, which means "always".

\begin{tabular}{|c|c|c|c|c|c|c|}
\hline & & Never & $\begin{array}{l}\text { Not } \\
\text { often }\end{array}$ & $\begin{array}{l}\text { Some- } \\
\text { times }\end{array}$ & Usually & Always \\
\hline 1 & $\begin{array}{l}\text { Before I make a decision, I think about how it } \\
\text { will affect me. }\end{array}$ & 1 & 2 & 3 & 4 & 5 \\
\hline 2 & $\begin{array}{l}\text { I say "no" to my friends if they want me to do } \\
\text { something that is wrong. }\end{array}$ & 1 & 2 & 3 & 4 & 5 \\
\hline 3 & I read when I have free time. & 1 & 2 & 3 & 4 & 5 \\
\hline 4 & I reach goals I have set for myself. & 1 & 2 & 3 & 4 & 5 \\
\hline 5 & I plan ahead for things that need to be done. & 1 & 2 & 3 & 4 & 5 \\
\hline 6 & I finish my school homework on time. & 1 & 2 & 3 & 4 & 5 \\
\hline 7 & I can talk to my friends about personal things. & 1 & 2 & 3 & 4 & 5 \\
\hline 8 & I look people in the eye when I talk with them. & 1 & 2 & 3 & 4 & 5 \\
\hline 9 & $\begin{array}{l}\text { I think about different ways I can solve a } \\
\text { problem before I decide. }\end{array}$ & 1 & 2 & 3 & 4 & 5 \\
\hline 10 & I try to get the facts before I solve a problem. & 1 & 2 & 3 & 4 & 5 \\
\hline 11 & I find it easy to get my point across. & 1 & 2 & 3 & 4 & 5 \\
\hline 12 & I try to solve problems without fighting. & 1 & 2 & 3 & 4 & 5 \\
\hline 13 & $\begin{array}{l}\text { I think about what I'm going to say before I } \\
\text { speak. }\end{array}$ & 1 & 2 & 3 & 4 & 5 \\
\hline 14 & $\begin{array}{l}\text { Before I make a decision, I think about how it } \\
\text { will affect other people. }\end{array}$ & 1 & 2 & 3 & 4 & 5 \\
\hline 15 & $\begin{array}{l}\text { I try to understand what the other person is } \\
\text { saying before I answer them. }\end{array}$ & 1 & 2 & 3 & 4 & 5 \\
\hline
\end{tabular}




\section{SECTION 3}

Directions: Read each statement and circle the answer that best describes you at the present time. The answers range from 1 , which means "strongly disagree", to 5, which means "strongly agree".

\begin{tabular}{|c|c|c|c|c|c|c|}
\hline & & $\begin{array}{l}\text { Strongly } \\
\text { Disagree }\end{array}$ & Disagree & Not Sure & Agree & $\begin{array}{l}\text { Strongly } \\
\text { Agree }\end{array}$ \\
\hline 16 & $\begin{array}{l}\text { I feel that I have a number of good } \\
\text { qualities. }\end{array}$ & 1 & 2 & 3 & 4 & 5 \\
\hline 17 & I do things that are considered safe. & 1 & 2 & 3 & 4 & 5 \\
\hline 18 & I am good at cooperating with a team. & 1 & 2 & 3 & 4 & 5 \\
\hline 19 & $\begin{array}{l}\text { I feel that I am at least as good as } \\
\text { most other people my age. }\end{array}$ & 1 & 2 & 3 & 4 & 5 \\
\hline 20 & I have a good attitude about myself. & 1 & 2 & 3 & 4 & 5 \\
\hline 21 & $\begin{array}{l}\text { I keep trying when things become } \\
\text { difficult. }\end{array}$ & 1 & 2 & 3 & 4 & 5 \\
\hline 22 & I like to learn new things at school. & 1 & 2 & 3 & 4 & 5 \\
\hline 23 & I set challenging goals for myself. & 1 & 2 & 3 & 4 & 5 \\
\hline 24 & $\begin{array}{l}\text { I think I am good at making and } \\
\text { keeping friends. }\end{array}$ & 1 & 2 & 3 & 4 & 5 \\
\hline 25 & $\begin{array}{l}\text { I think that doing well in school is } \\
\text { important. }\end{array}$ & 1 & 2 & 3 & 4 & 5 \\
\hline 26 & $\begin{array}{l}\text { When I have a problem, I try to figure } \\
\text { out just what the problem is. }\end{array}$ & 1 & 2 & 3 & 4 & 5 \\
\hline 27 & $\begin{array}{l}\text { On the whole, I am satisfied with } \\
\text { myself. }\end{array}$ & 1 & 2 & 3 & 4 & 5 \\
\hline 28 & $\begin{array}{l}\text { I try to think about what will happen if } \\
\text { I solve a problem in different ways. }\end{array}$ & 1 & 2 & 3 & 4 & 5 \\
\hline 29 & $\begin{array}{l}\text { The LIFE program helped me feel } \\
\text { good about who I am. }\end{array}$ & 1 & 2 & 3 & 4 & 5 \\
\hline 30 & $\begin{array}{l}\text { The LIFE program helped me deal with } \\
\text { other people better. }\end{array}$ & 1 & 2 & 3 & 4 & 5 \\
\hline
\end{tabular}

